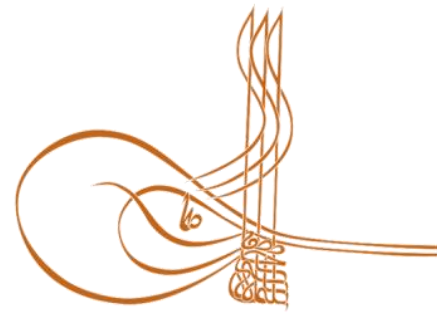

www.turkishstudies.net/economy
Turkish Studies - Economics, Finance, Politics

eISSN: $2667-5625$

Research Article / Araștırma Makalesi

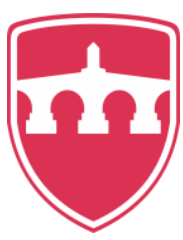

INTERNATIONAL BALKAN

UNIVERSITY

Sponsored by IBU

\title{
Kamu Personeli Tarafından İşlenen Zimmet Suçlarına Yönelik Türkiye Genelinde Bir Araştırma
}

\author{
A Research Across Turkey Regarding Embezzlement Crimes Perpetrated By Public Sector \\ Personnel
}

İsmail Kaban*

\begin{abstract}
The state provides various services to citizens through public employees. These services are mainly financed from budgetary sources. The sources of the general budget are tax and similar public financial resources collected from a large number of individuals and firms. The revenues collected by the state through taxation are used during the year with different incentives in the form of current expenditures, transfer expenditures and investment expenditures. In the process of collecting fiscal income and converting them into expenditures for various purposes in the public sector, many transactions are performed and these are carried out by a high number of personnel. Various fraud risks arise due to the high number of public employees and the variety of transactions performed. Research shows that embezzlement acts, which are misuse of assets, are the most common frauds in the public sector. Embezzlement is expressed in the form of the disposing of a public personnel in the interest of himself or another person on an asset transferred to him due to his duty. This paper aimed to evaluate embezzlement crimes perpetrated by public sector personnel in Turkey. The research was carried out on forensic statistics published by the Ministry of Justice. Within this framework, the difference tests were carried out regarding the embezzlement actions that were subject to the criminal cases between 20092017 in terms of year, gender and region and the findings are discussed within the scope of fraud theory. The results of this study show that embezzlement actions carried out in the Turkish public sector have significant differences in terms of gender and region, but not in terms of years.
\end{abstract}

Structured Abstract: Introduction and Purpose of the Study: The state authority provides a variety of public services, such as justice, security, health, education and infrastructure services, to all those who are bound by citizenship. The balance of income and expenditure related to the services provided to citizens is provided through annual budgets. Public sector are among the most important actors in the national economies due to the high public expenditures. High expenditures made by the state are compensated by the tax and the tax-related incomes collected from the citizens. Collecting large amounts of tax and similar income from a large number of citizens through mass transactions brings various fraud risks related public personnel. The

\footnotetext{
* SMMM, Dr. Öğr. Üyesi, Tokat Gaziosmanpaşa Üniversitesi, Tokat Sosyal Bilimler Meslek Yüksekokulu, Muhasebe ve Vergi Bölümü

Asst. Prof. Dr. Tokat Gailosmanpasa University, Vocational School of Social Sciences, Department of Accounting and Tax ORCID 0000-0003-4138-244X

ismail_kaban@yahoo.com
}

Cite as/ Atıf: Kaban, İ. (2020). Kamu personeli tarafından işlenen zimmet suçlarına yönelik Türkiye genelinde bir araştırma, Turkish Studies - Economy, 15(1), 207-224. https://dx.doi.org/10.29228/TurkishStudies.40139
Received/Geliş: 12 December/Aralık 2019
Checked by plagiarism software
Accepted/Kabul: 25 March/Mart 2020
Published/Yayın: 30 March/Mart 2020
Copyright $(C)$ INTAC LTD, Turkey 
resources collected by the state are allocated to different fields in the form of current expenditures, investment expenditures and transfer expenditures and these expenditures are subject to numerous transactions. The fraud risks that arise during the collection of budget revenues are also valid in the expenditure of budget resources. Inspection boards and internal audit systems established in public institutions aim to combat fraud risks effectively. In this study, embezzlement acts carried out between 2009-2017 years in the Turkish public sector were analyzed. Thus, it is aimed to present findings and suggestions to related parties in order to combat fraud more effectively in public. This study is the first in the domestic literature.

Literature Research: There are many studies in the literature on fraud audit and embezzlement. However, on the basis of forensic statistics, there is no research article on the embezzlement actions carried out by public personnel in Turkey. Therefore, it is thought that the study has a high potential to contribute to the literature.

Method: In the research, secondary data obtained by data collection technique in the form of document analysis were used. The data constituting the basis of the analyzes were obtained from the documents containing crime statistics on the official website of the Ministry of Justice. In accordance with Article 247 of Law no. 5237, the number of embezzlement cases opened in criminal courts between 2009 and 2017 was accepted as the base data. Normal distribution analysis was performed on the data obtained from the official website of the Ministry. As a result of the analysis, nonparametric tests were applied on the data which was found not to have normal distribution. In this context, through SPSS PASW 18 Statistics program, it is performed frequency analysis based on the number of embezzlement crimes committed over the years. In addition, Mann-Withney U test on the basis of gender and Kruskall-Wallis H tests on the basis of regions and years were performed.

Findings: As a result of the Mann-Withney U test on embezzlement crimes by gender, there was a significant difference between the men and women working in the public sector in terms of embezzlement action $(\mathrm{p}<0.05)$ and it was found that males committed more embezzlement attempts than women.

According to the Kruskall-Wallis $\mathrm{H}$ test on embezzlement crimes according to the region, there is a significant difference in the number of embezzlement actions per 1,000,000 people in the public sector ( $p$ $<0,05)$. Accordingly, the highest number of embezzlement acts took place in the Aegean Region and the lowest embezzlement action took place in the Southeastern Anatolia Region.

As a result of the Kruskall-Wallis $\mathrm{H}$ test on embezzlement crimes by years, it was found that there was no significant difference in the number of embezzlement crimes committed in the public sector by years,

Conclusion and Evaluation: The findings obtained in terms of gender coincide with the findings presented in the ACFE reports, which are the most comprehensive surveys of fraud worldwide. It is seen that the highest embezzlement actions in the region are in the Aegean and the lowest embezzlement attempts are in Southeast Anatolia It can be said that living conditions in Southeast Anatolia are easier and the cost of living is relatively low. It can also be said that this situation prevents financial pressure on public personnel and suppresses embezzlement initiative. In addition, it can be said that the stronger moral judgments in Anatolia contributed to the formation of this picture. The fact that the lowest embezzlement initiative took place in Eastern and Southeastern Anatolia supports this finding. The result of the research could be useful for can be effectively struggled against fraud risks in the internal audit planning in Turkish the public sector. Today, it is seen that both internal audit units and inspection boards are available separately in public institutions. In order not to cause a conflict of duties and powers, the activities to be carried out by the relevant units should be subject to proper planning and coordination. According to Law No. 5018, internal audit units are prevented from conducting investigations while conducting control, audit, examination and research activities. Although the international internal audit standards emphasize that the primary task of the internal audit unit is not to conduct investigations, it is stated that the investigation task can be carried out by internal auditors who are experts in especially fraudulent transactions and irregularities. It can be said that making such arrangements within the legal framework will make a positive contribution in terms of align legislation with international standards and combating fraud more effectively. Finally, it can be stated that the systematic reporting of fraudulent transactions performed in the public sector within the framework of the age, training level and experience period of the personnel and similar criteria is of critical importance for the fraud detection and prevention. Thus, it is thought that a more effective fight against fraud will be possible in public sector.

Keywords: Public Sector, Occupational Frauds, Forensic Accounting 
JEL Classification Codes: H83, K42, M42

Öz: Devlet tarafindan vatandaşlara kamu çalışanları aracılı̆̆ıla muhtelif hizmetler sunulmaktadır. Söz konusu hizmetlerin finansmanı ağırlıklı olarak bütçe kaynaklarından sağlanmaktadır. Genel bütçenin kaynakları, çok sayıda kişi ve firmadan toplanan vergi ve benzeri kamu mali gelirleridir. Devletin vergilendirme yoluyla elde ettiği gelirler, cari harcamalar, transfer harcamaları ve yatıım harcamaları biçiminde farklı saiklerle yıl içinde kullanılmaktadır. Kamu sektöründe çeşitli amaçlarla gelir elde edilmesi ve bunların harcamalara dönüştürülmesi sürecinde çok sayıda işlem yapılmakta ve bunlar yüksek sayıda personel tarafindan yürütülmektedir. Kamuda çalışan personel sayısının yüksekliği ve icra edilen işlem çeşitliliği sebebiyle birtakım hile riskleri ortaya çıkmaktadır. Yapılan araştırmalar kamu sektöründe varlıkların kötüye kullanılması niteliğindeki zimmet eylemlerinin en sık gerçekleştirilen hileler olduğunu göstermektedir. Zimmet, görevi nedeniyle zilyetliği kendisine devredilen bir kıymet üzerinde bir kamu personelinin kendisi veya başkasının çıkarına olarak tasarrufta bulunması biçiminde ifade edilmektedir. Bu çalışmada Türkiye kamu sektöründe çalışan personel tarafından gerçekleştirilen zimmet eylemlerinin değerlendirilmesi amaçlanmıştır. Araştırma Adalet Bakanlığı tarafından yayınlanan adli istatistik verileri üzerinden yürütülmüştür. Bu çerçevede 20092017 yılları arasında ceza davalarına konu olan zimmet eylemlerine ilişkin olarak yıl, cinsiyet ve bölge bağlamında fark analizleri gerçekleştirilmiş olup ortaya çıkan istatistiki bulgular hile teorisi çerçevesinde tartışılmıştır. Araştırmadan elde edilen sonuçlar, kamu sektöründe gerçekleştirilen zimmet eylemlerinin cinsiyet ve bölge açısından anlamlı farklılıklar taşıdığını, yıl açısından ise anlamlı bir farklılık taşımadığını göstermektedir.

Anahtar Kelimeler: Kamu Sektörü, Çalışan Hileleri, Adli Muhasebe

\section{Giriş}

Devlet otoritesi, kendisine vatandaşlık bağı ile bağlı olan herkese adalet, güvenlik, sağlık, eğitim ve altyapı hizmetleri gibi çeşitli kamusal hizmetler sunmaktadır. Vatandaşlara sunulan söz konusu hizmetlere ilişkin gelir ve harcama dengesi yıllık olarak yapılan bütçeler yoluyla sağlanmaktadır. Yapılan kamu harcamalarının çok yüksek tutarlara ulaşması sebebiyle kamu sektörü ülke ekonomilerinde en önemli aktörler arasında yer almaktadır. Dünyada piyasa ekonomisinin öne çıktığı son yıllarda kamunun ülke ekonomilerindeki ağırlığı görece azalsa da devletin ekonomik aktivitedeki kritik rolü devam etmektedir. Devlet yaptığı yüksek harcamaları vatandaşlardan topladığı vergi ve vergi benzeri gelirler yoluyla karşılamaktadır. Geniş bir vatandaş kitlesinden yığın işlemler icra edilerek yüksek tutarda vergi vb. gelir tahsil edilmesi kamu personeli nezdinde çeşitli hile risklerini de beraberinde getirmektedir. Devletin topladığı kaynaklar cari harcamalar, yatırım harcamaları ve transfer harcamaları biçiminde farklı alanlara özgülenmekte olup söz konusu harcamalar yüksek sayıda işlemler üzerinden gerçekleştirilmektedir. Bütçe gelirlerinin tahsil edilmesi aşamasında ortaya çıkan hile riskleri bütçe kaynaklarının harcamalara özgülenmesine ilişkin işlemlerin icrası aşamasında da geçerlidir.

Türkiye'de kamu sektörü 2018 Mart ayı itibarıyla 3,1 milyon kişiye istihdam sağlamaktadır. Çalışan sayısının çok yüksek olması ve kamunun sahip olduğu sınırlı iç denetim kaynakları ile çalışanların gerçekleştirdiği bütün işlemlerin denetim ve kontrolünün mümkün olmaması sektörün hileli işlemler konusundaki kırılganlığını artırmaktadır. Diğer taraftan vatandaşların eğitim düzeyi, yaş vb. gibi sahip olduğu farklı demografik özellikler ve kamu personeline olan güven gibi psikolojik etkenler de hile riski doğuran diğer faktörler olarak ortaya çıkmaktadır. Vatandaşlar çeşitli sebeplerle doğan mali yükümlülüklerini kamu kurumlarındaki veznedarlara nakit olarak ya da kurumlarca geliştirilen yazılımları kullanmak suretiyle banka havalesi şeklinde ödemekte veya kredi kartı ödemesi yaparak yerine getirmektedirler. Vatandaşlardan yapılan tahsilatlar kamu personeli tarafından hileli işlemlere konu edilebilmektedir. Tahsil edilen nakit paralardan ya da mali yükümlülüklerin yatırıldığı kurum hesaplarından muhtelif tutar ve zamanda kamu personelinin uhdesine para geçirmesi şeklinde vuku bulan bu işlemler zimmet olarak adlandırılmaktadır. Zimmet 
eylemine konu olan tutarlar kamunun toplam gelirleri içinde oldukça düşük kalmaktadır. Dolayısıyla söz konusu hileli eylemlerden kaynaklanan kayıplar kamusal faaliyetlerin devamlılı̆̆ını etkilemese de etkin bir denetim ve tespit sistemi yoluyla caydırıcılık sağlanamaması durumunda zimmet vakaları giderek yaygınlaşarak telafisi oldukça zor doğrudan ve dolaylı maliyetlere yol açabilecektir. Kamu otoritesi ile vatandaş arasında kurulan güven ilişkisini zedeleyecek bu tür hilelerin yaygınlaşmasının önüne geçmek amaciyla ilgili kurumlar teftiş kurulları ve iç denetim sistemleri kurmakta ve gerekli önlemleri almaktadır.

Kamu kurumlarında ihdas edilen teftiş kurulları ve iç denetim sistemleri sayesinde hile riskleri ile etkin olarak mücadele edilmesi amaçlanmaktadır. Bu çalışmada Türkiye kamu sektöründe 2009-2017 yılları arasında gerçekleştirilen zimmet eylemleri incelenmiştir. Böylece kamuda hile ile daha etkin mücadele edilebilmesine ilişkin olarak ilgili taraflara bulgu ve öneriler sunulmas1 amaçlanmıştır. Araştırma kamu personelinin zimmet suçları hakkında ilgili dönemde Türkiye ölçeğinde açılan davaların tamamını kapsamakta ve alanında ilk olma özelliğini taşımaktadır.

\section{Literatür Taraması}

Hile denetimi ve zimmet konusunda daha önce Türkçe ve yabancı literatürde gerçekleştirilen bazı örnek çalışmalar aşağıda sunulmuştur. 
Tablo 1: Hile Denetimi ve Zimmet Konusunda Türkçe ve Yabancı Literatürdeki Bazı Çalışmalar

\begin{tabular}{|c|c|c|}
\hline Yazar & Yll & Sonuçlar \\
\hline Gloeck ve de Jager & 2005 & $\begin{array}{l}\text { Çalışmada Güney Afrika kamu sektöründeki hile olgusu incelenmiştir. } \\
\text { Yapılan araştırma sonucunda muhtelif eyaletlerde, farklı büyüklük ve } \\
\text { türdeki kurumlar vb. gruplarda farklı hile profillerinin söz konusu olduğu } \\
\text { bulgusuna ulaşılmıştır. Ulaşıllan bulguları hile ile mücadele ve tespit } \\
\text { süreçlerinde doğru yöntemlerin belirlenmesine ve Güney Afrika kamu } \\
\text { sektöründe genel hile profilinin anlaşılmasına katkı sağlaması } \\
\text { hedeflenmiş̧tir. }\end{array}$ \\
\hline Kayım & 2009 & $\begin{array}{l}\text { Çalışmada iç denetçilerin mevzuatta sayılan görevlerin yanında soruşturma } \\
\text { görevini de yürütüp yürütemeyeceği tartış1lmıştır. İç denetçilerin } \\
\text { uluslararası standartlar ve uygulama önerilerinde soruşturma görevine dahil } \\
\text { edilmelerinin istisnai bir durum olarak düzenlendiği ifade edilmiş̧ir. } \\
\text { Türkiye'de iç denetçilere soruşturma yetkisi verilmesi durumunda iç } \\
\text { denetimin muhteva olarak geleneksel denetime benzeme ihtimalinin } \\
\text { doğacağı ileri sürülmüştür. }\end{array}$ \\
\hline Okoye ve Gbegi & 2013 & $\begin{array}{l}\text { Araştırmada, Nijerja'nın Kogi eyaletine bağlı kamu kurumlarında bir hile } \\
\text { tespit ve önleme aracı olarak adli muhasebenin incelenmesi amaçlanmıştır. } \\
\text { Bu kapsamda birincil ve ikincil veriler uygun bir şekilde kullanılmış ve } \\
\text { seçilen } 5 \text { belediye üzerinde anket uygulaması yapılmıstır. Anket verileri } \\
\text { üzerinde gerçekleștirilen Anova testi sonucunda adli muhasebenin kamu } \\
\text { sektöründe hileli işlemlerin varlığın anlamlı bir oranda azalttığ bulgusuna } \\
\text { ulaşılmıştır. Ayrıca profesyonel adli muhasebeciler ve geleneksel dış } \\
\text { denetçiler arasında da önemli bir fark bulunduğu, adli muhasebecilerin } \\
\text { kamu kurumlarında hile tespit ve önleme süreçlerine daha fazla yardımc1 } \\
\text { olabileceği saptanmıştır. }\end{array}$ \\
\hline İtişgen & 2013 & $\begin{array}{l}\text { Çalışmada, Türk Ceza Kanunu ve Bankacılık Kanununda düzenlenen } \\
\text { zimmet suçlarının benzerlik ve farklılıkları Yargıtay kararları ve doktrindeki } \\
\text { görüşler ışğında değerlendirilmiştir. }\end{array}$ \\
\hline Şentürk ve Kasap & 2013 & $\begin{array}{l}\text { Çalışmada beyaz yaka suçları kavramsal bir açıdan etraflıca incelenmiştir. } \\
\text { Bu suçların meydana getirdiği ekonomik kayıplar örnekler üzerinden } \\
\text { sunularak söz konusu suiistimallerin sektörler ve kurumlar üzerinde ne } \\
\text { kadar etkili olduğu tartış1lmıştır. }\end{array}$ \\
\hline Aslan & 2013 & $\begin{array}{l}\text { Çalışmada zimmet suçu ile ilgili genel bilgilere yer verilmiş olup suçun } \\
\text { tarihsel gelişimi ve Türk Ceza Kanunu'nda var olan düzenleme } \\
\text { irdelenmiştir. Karşılaştırma imkân vermesi sebebiyle Bankacılık } \\
\text { Kanunu'nda düzenlenen zimmet suçuna ilişkin özet bir değerlendirme } \\
\text { yapılmıştır. }\end{array}$ \\
\hline Othman vd. & 2015 & $\begin{array}{l}\text { Araştırmada Malezya kamu sektöründe yolsuzluk ve hilelerin tespit ve } \\
\text { önlenmesi için kullanılan yöntemlerin ve bunların muhasebeciler nezdinde } \\
\text { algılanan etkisinin ortaya konulması amaçlamışıtı. Muhasebecileri ve iç } \\
\text { denetçileri kapsayan anket uygulaması sonucunda en etkili hile tespit ve } \\
\text { önleme yöntemleri olarak faaliyet denetimleri, güçlendirilmiş denetim } \\
\text { komiteleri, gelişmiş iç kontroller, hile raporlaması uygulamalar, personel } \\
\text { rotasyonu, yolsuzluk (etik) bildirim hatları ve adli muhasebeci çalıştırılması } \\
\text { gibi yöntemlerin öne çıktığ bulgusuna ulaşıllmıştır. }\end{array}$ \\
\hline
\end{tabular}

\section{3. Çalıșan Hileleri ve Kamu Sektöründe Hile Denetimi}

Hile, bir bankadaki ATM makinesine benzemektedir. Hem ATM makinesi hem de hile ihtiyaç duyulan veya arzulanan bir miktar paraya sahip olmak için kullanılmaktadır. ATM makinesi, mevduat sahiplerinin bankadan istedikleri miktarda paray1 hukuka uygun olarak çekmelerini mümkün kılarken hilede, bir organizasyondan para veya parasal değeri olan kıymetlerin hilekâr tarafından hukuku aykırı olarak mâl edinilmesi söz konusu olmaktadır (Vona, 2008:3). Hile terimi 
hırsızlık, yolsuzluk, zimmet, kara para aklama ve rüşvet gibi fiilleri kapsamaktadır. Hile kavramı farklı şekillerde tanımlanmakla birlikte esasen, dürüst olmayan bir şekilde kişisel bir kazanç elde etmeyi veya bir başkasına zarar vermeyi amaçlayan aldatıcı eylemleri ifade etmektedir (CIMA, 2009a:7). Tüm hile eylemleri genel olarak aşağıdaki dört temel unsur üzerinden özetlenebilir (Golden vd., 2006:2):

- Sahibi olunmayan maddi yapının suistimal edilmesi (haksız kazanç),

- Dürüstlük kurallarına aykırı olarak suistimalin kasıtlı olması (kasıt),

- Temsil veya işlem yapma yetkisi olan kişiye güvenilmesi (güven),

- Bunların hepsinin sonucunda maddi bir zararla karşılaşılması (zarar).

Mesleki hile, iç dolandırıcılık, çalışan dolandırıcılığı, çalışan hırsızlığı ve zimmet dahil olmak üzere muhtelif şekillerde ifade edilmektedir. "Mesleki hile" veya "iç dolandırıcılık" kavramları, kurumsal hile eylemleri tartış1lırken sıklıkla tercih edilir, çünkü diğer terimler biraz daha sınırlayıcı iken bu kavramlar çalışan suiistimali konusunda daha kapsayıcı bir içerik sunmaktadır (Coenen, 2008:6). Mesleki hile, bir kişinin mesleki yetkisinin kasıtlı olarak suiistimal edilmesi veya haksız kullanılması yoluyla çalıştığı kuruluşun kaynaklarının veya varlıklarının kişisel zenginleşme amaciyla kullanılması olarak tanımlanmaktadır (ACFE, 2018a:6). Diğer bir ifade ile mesleki hile, bünyesinde çalışılan kuruluşun kaynaklarının veya varlıklarının kasıtlı olarak kötüye kullanılması yoluyla kişisel zenginlik elde edilmesi yönünde başvurulan girişimlerdir (DiNapoli, 2008:1). Bir organizasyonda çok fazla türde hile ile karşılaşılabilir. Bunların arasında yaygın olarak gerçekleşen bazı hile türleri şunlardır (CIMA, 2009b:4):

- Nakit ve fiziki varlık hırsızlı̆̆g,

- Hesaplardaki parasal değerlerin suiistimal edilmesi,

- Maaş bordrosu dolandırıcilığı,

- Sahte gider talepleri,

- Fiili olarak çalışmayan personele yapılan ödemeler,

- Rüşvet ve yolsuzluk.

Bir kurumu veya organizasyonu etkileyen mesleki hileler üç ana kategoride sınıflandırılmaktadır. Bunlar varlıkların kötüye kullanılması, hileli tablo düzenlenmesi ve yolsuzluk olarak ifade edilmektedir. Varlıkların kötüye kullanılması eylemleri nakit varlıklar veya nakit olmayan varlıklar üzerinde gerçekleştirilebilirken hileli tablolar finansal tablolar veya finansal olmayan tablolar biçiminde düzenlenebilmektedir. Son olarak yolsuzluk, yasadışı hediyeler, rüşvet veya haraç biçiminde ortaya çıkabilmektedir (CIMA, 2009b:5). Uluslararası Sertifikalı Hile Denetçileri Birliği (ACFE) tarafından hile ağacı kavramı kullanılarak benzer bir sınıflandırma yapılmaktadır. Hile türlerinin dağılımında en yüksek payı bütün sektörler bazında varlıkların kötüye kullanılması almaktadır (ACFE, 2018a:10-11). ACFE tarafından yapılan 2018 yılı hile araştırmasına göre kamu kurumlarının maruz kaldığı hilelerin türleri ve bunların oransal dağılımı aşağıdaki tabloda gösterilmiştir.

Tablo 2: Kamu Kurumlarının Maruz Kaldığı Hile Türlerinin Dağılımı

\begin{tabular}{|c|c|}
\hline Hile Türü & Sayısal Olarak Dağlım (\%) \\
\hline Yolsuzluk & 50 \\
\hline Varlıkların Kötüye Kullanılması & 45 \\
\hline Finansal Tablo Hileleri & 5 \\
\hline
\end{tabular}

Kaynak: ACFE, 2018a:25.

Turkish Studies - Economy, 15(1) 
Tüm sektörler bazında varlıklar kötüye kullanılması ilk sırada yer alan hile türü iken kamu sektöründe yolsuzluk hile türleri arasında ilk sırada bulunmaktadır. Ancak varlıkların kötüye kullanılması ile yolsuzluk arasında $\% 5$ gibi çok küçük bir fark bulunmaktadır. Kamu sektöründe finansal tablo hileleri \%5 gibi oldukça düşük bir oran teşkil etmektedir.

ACFE tarafindan yapılan araştırmaya göre hileye maruz kalan organizasyonlar arasında kamu kurumları, özel sektör firmaları ve halka açık firmaların ardından üçüncü sırada yer almaktadır (ACFE, 2018a:20). Araştırma 2690 mesleki hile vakasını kapsamakta olup kamu sektöründe toplam hile vakalarının \%6,21'ini teşkil eden 184 adet hile girişimi gerçekleşmiştir. Kamu sektöründe bu hile girişimlerinin sonucunda ortalama 110.000 \$ kayba maruz kalınmıştır. (ACFE, 2018a:25). Organizasyonlarda hileli işlemlerin önlenmesine ilişkin olarak geliştirilen tedbirler arasında iç denetim sistemi, mesleki etik kuralları, bağımsız denetimin, yönetim değerlendirmesi, sıcak ihbar hatları, çalışan destek programları ve çalışanlara verilen hile eğitimleri gibi faaliyetler bulunmaktadır. İç denetim sistemi, bu faaliyetler arasında mesleki etik kuralları ve bağımsız denetimden sonra yaygınlık açısından üçüncü sırada (ACFE, 2018a:27) olup mesleki hilelerin tespit edilmesi açısından ise iç denetim faaliyetleri ihbardan sonra ikinci sırada yer almaktadır (ACFE, 2018a:17). Kamu sektöründe mesleki hilelere zemin hazırlayan faktörler arasında iç kontrol zayıflıkları (\% 30) ve mevcut iç kontrol prosedürlerinin önemsenmemesi (\%18) ağılıklı oranı teşkil etmektedir (ACFE, 2018b:13).

Hile denetimi hukuki sorgulama teknikleri ile standart denetim prosedürlerinin bir araya geldiği özel bir iç denetim yöntemidir (Emir, 2008:110). Hile ve dolandırıcılıkların, gelir ve varlık kayıplarının önlenmesinde iç kontrol sistemi ve iç denetim faaliyetinin etkinliği önemli rol oynamaktadır (Uzun, 2009:62). Kamu sektöründe iç denetim süreçleri 5018 sayılı Kamu Mali Yönetimi ve Kontrol Kanunu ile düzenlenmiş olup ilgili Kanunda iç denetim, kamu idaresinin çalışmalarına değer katmak ve geliştirmek için kaynakların ekonomiklik, etkililik ve verimlilik esaslarına göre yönetilip yönetilmediğini değerlendirmek ve rehberlik yapmak amacıyla yapılan bağımsız, nesnel güvence sağlama ve danışmanlık faaliyeti olarak tanımlanmıştır (5018 sayılı Kamu Mali Yönetimi ve Kontrol Kanunu, md. 63). 5018 sayılı Kanun ile kamu tüzel kişiliği taşıyan kurumlarda iç denetim birimi tesis edilmiş olup söz konusu birimde çalışan iç denetçilerin görevleri olarak risk analizlerine göre mali yönetim ve kontrol süreçlerinin değerlendirmesi, harcamaların stratejik amaç ve hedeflere uygunluğunun değerlendirilmesi, bu bağlamda kaynakların etkin, etkili ve ekonomik bir şekilde kullanılmasına yönelik iyileştirme önerilerinde bulunulması biçiminde muhtelif faaliyetler sayılmıştır. İç denetçilerin hileli eylemlerin tetkiki ile ilgili sorumluluğu denetim sırasında ya da denetim sonucunda konusu suç teşkil edebilecek ya da idari, mali yaptırım gerektiren bir durumla karşılaştığında sadece durumu tespit ederek destekleyici belgeleri ile birlikte konuyu idarenin en üst amirine bildirmekle sınırlıdır (Kayım, 2009:121). İç Denetim Koordinasyon Kurulu (İDDK) tarafından yayınlanan ve iç denetçilerin çalışma esas ve usullerini düzenleyen yönetmelikte de iç denetçilerin, faaliyetler sırasında edinilen bilgi, belge ve bulguların analizi sonucu ortaya çıan emarelerden, detaylı inceleme veya soruşturmayı gerektirecek hususları ayırt edecek yeterliliğe sahip olmaları beklenmektedir (IDDK, 2006:md.32). Hileli eylemlerin tespit edilmesi sonrasında bunların üst yöneticiye bildirilmesi ile iç denetçilerin görevi sona erer (Şahin, 2008:294). İç denetçilerden hileli eylemlerin tespiti konusunda yetkinlik beklenirken suç teşkil eden söz konusu fiillerle ilgili iç denetçilerin soruşturma yapma yetkisi bulunmamaktadır.

Kamu sektöründe sunulan hizmetler ve yürütülen faaliyetler sırasında ortaya çıkan usulsüzlüklerle ilgili soruşturma yapma yetkisi Devlet Denetleme Kurulu ile kamu kurum ve kuruluşları bünyesinde kurulan teftiş kurullarına aittir. Devlet Denetleme Kurulu ve kamu kurum ve kuruluşlarının teftiş kurulları bünyesinde çalışan denetçi ve müfettişler ilgili yasal düzenlemelerden aldıkları yetkiye dayanarak hileli eylemler gerçekleştiren kamu personeli hakkında hukuki yönü ağırlık taşıyan inceleme ve soruşturma çalışmaları yürütmektedir. Devlet Denetleme Kurulu denetçileri yargı organları dışındaki tüm kamu kurum ve kuruluşlarında çalışanların, ceza ve disiplin 
hukukundan ve diğer mevzuattan doğan sorumluluklarının tespit edilmesine yönelik denetim, inceleme, araştırma ve soruşturma faaliyetlerinin yürütülmesinden sorumlu olup (5 sayılı Cumhurbaşkanlığı Kararnamesi, 2018:md.2) diğer kamu kurumlarındaki müfettişler kendi kurum ve kuruluşlarında çalışan kamu personelinin hileli eylemlerine ilişkin ceza ve disiplin hukukundan kaynaklanan sorumlulukların tespitine ilişkin inceleme ve soruşturma faaliyetlerinin yürütülmesi konusunda görevlendirilmiş ve yetkilendirilmiştir.

Teftiş kurulları ile iç denetim birimlerinin yürürlükteki mevzuatları göz önüne alındığında; görevlerde çakışmaların yaşanması kuvvetle muhtemel görülmektedir (Yaman, 2011:27). Dolayısıyla kamu kurum ve kuruluşlarında iç denetim birimleri ve teftiş kurulları aracılığıyla yürütülen denetim faaliyetleri çift başlı bir görüntü arz etmektedir. Her ne kadar iç denetim faaliyetleri modern denetimin gereği olarak kurgulanmış olsa da hâlihazırda varlığını sürdüren teftiş kurullarından da iç denetim biriminden talep edilen birçok görev ve hizmet beklenmektedir. Son yıllarda Ticaret Bakanlığı, Tarım ve Orman Bakanlığı, Gençlik ve Spor Bakanlığı ve Çevre Şehircilik Bakanlığı gibi bazı kamu kurumlarında geleneksel adı "Teftiş Kurulu Başkanlığı” olarak bilinen denetim birimlerinin "Rehberlik ve Teftiş Kurulu Başkanlığı" adı ile yapılandırıldığı görülmektedir. $\mathrm{Bu}$ durum günümüzde iç denetim biriminden beklenen rehberlik ve danışmanlık fonksiyonunun teftiş kurullarının faaliyetleri arasına da dahil olacağını gösteren bir işaret olarak değerlendirilebilir. Bu anlamda iç denetim birimleri ile teftiş kurullarından beklenen denetim hizmetlerinin çerçevesinin net bir şekilde çizilerek ayrıştırılması ve aralarında etkin bir koordinasyon sağlayacak mekanizmaların kurulması önem arz etmektedir. Uluslararası İç Denetçiler Enstitüsü tarafından yayınlanan iç denetim standartlarında iç denetçinin hileli eylemlerle ilgili inceleme ve soruşturma faaliyetleri yürütmesine engel teşkil eden bir hüküm bulunmamaktadır. İç denetçilerin hile soruşturmalarını yürütmeleri istisnai bir görev olarak değerlendirilmekte olup kurumun hile denetimi için bu konuda uzman ve sertifikalı denetçiler istihdam etmesi tavsiye edilmektedir.

Bir suistimalden şüphelenildiğinde, iç denetim biriminin araştırma, analiz ve delil toplama hususlarında uzmanlık becerilerine sahip olması koşuluyla, iç denetim birimi gerekli araştırma ve soruşturmaları yapabilir (IIA, 2009:23-24). Buradan hareketle kamu kurumlarında da iç denetim birimine soruşturma yetkisinin verilebileceği söylenebilir. İç denetçilerin sertifikasyon süreçlerinin desteklenerek kurumlarda hile uzmanlığı sertifikasına (CFE) sahip olan denetçilerin bulundurulması kamu sektöründe yürütülen hile denetiminde etkinlik sağlayacaktır.

\section{5237 sayılı Kanun'da Zimmet Suçu}

Zimmet, ekonomik suç veya beyaz yaka suçları kavramları içinde anılan bir suç türüdür. Ekonomik suçları da kapsayan beyaz yaka suçları ilk kez literatürde Sutherland tarafından 1939 yılında tanımlanmıştır. Buna göre beyaz yaka suçları, mesleği süresince sosyal bir konuma sahip ve itibarlı bir durumda olan kişiler tarafından işlenen suçlardır (Bozkurt, 2016:103). Beyaz yaka suçları, şiddete dayanmaksızın failin mesleğinden kaynaklanan konumunu kullanarak zimmet, haraç ve rüşvet vb. usulsüz eylemlere başvurmasını ifade etmektedir. Dolayısıyla bu suçlarda kişinin mesleğinden ve konumundan faydalanarak haksız kazanç sağlaması söz konusu olmaktadır (Dursun, 2005:215). Türk hukuk sisteminde zimmet, 5237 sayılı Türk Ceza Kanunu'nda kamu görevlileri için ve 5411 sayılı Bankacılık Kanunu'nda banka personeli için özel bir beyaz yaka suçu olarak düzenlenmiştir.

5237 sayılı Kanun'da zimmet suçuna ilişkin hükümler 247 ve 249'uncu maddeler arasında düzenlenmiştir. Kanun'un ilgili maddelerinde zimmet etkin pişmanlık ve daha az cezayı gerektiren haller yer almakta olup ilgili hükümler şöyledir (5237 sayılı Türk Ceza Kanunu,:md.247-249): 


\section{Zimmet}

Madde 247- (1) Görevi nedeniyle zilyedliği kendisine devredilmiş olan veya koruma ve gözetimiyle yükümlü olduğu malı kendisinin veya başkasının zimmetine geçiren kamu görevlisi, beş yıldan oniki yıla kadar hapis cezası ile cezalandırılır.

(2) Suçun, zimmetin açığa çıkmamasını sağlamaya yönelik hileli davranışlarla işlenmesi halinde, verilecek ceza yarı oranında artırılır.

(3) Zimmet suçunun, malın geçici bir süre kullanıldıktan sonra iade edilmek üzere işlenmesi halinde, verilecek ceza yarı oranına kadar indirilebilir.

Etkin pişmanlık

Madde 248- (1) Soruşturma başlamadan önce, zimmete geçirilen malın aynen iade edilmesi veya uğranılan zararın tamamen tazmin edilmesi halinde, verilecek cezanın üçte ikisi indirilir.

(2) Kovuşturma başlamadan önce, gönüllü olarak, zimmete geçirilen malın aynen iade edilmesi veya uğranılan zararın tamamen tazmin edilmesi halinde, verilecek cezanın yarısı indirilir. Etkin pişmanlığın hükümden önce gerçekleşmesi halinde, verilecek cezanın üçte biri indirilir.

Daha az cezayı gerektiren hal

Madde 249- (1) Zimmet suçunun konusunu oluşturan malın değerinin azlığı nedeniyle, verilecek ceza üçte birden yarıya kadar indirilir.

5237 sayılı Kanun'un 247'inci maddesinin birinci fikrasında suçun basit hali ve ikinci fikrasında suçun nitelikli hali açıklanmıştır. Maddenin üçüncü fikrasında ise suçun konusu olan kıymetin malik olmak niyetiyle değil geri verilmek amacıyla edinilmesi durumunu oluşturan kullanma zimmetine yer verilmiştir. Kanun'un 248 'inci maddesinde soruşturma veya kovuşturma başlamadan önce zimmete geçirilen malın iade edilmesini içeren etkin pişmanlık halleri doğrultusunda uygulanacak ceza indirimleri düzenlenmiştir. Son olarak 249'uncu maddede ise zimmet suçuna konu olan malın değerinin azlığı nedeniyle yapılacak ceza indirimi açıklanmıştır.

Zimmet suçu ile korunan hukuki değer hem devletin vatandaş nezdindeki itibarı hem de mali menfaatleridir (İtişgen, 2013:640). Zimmet suçunun maddi konusunu taşınır ve taşınmaz mallar oluşturmaktadır. Bu malların zilyetliğinin kamu görevlisine devredilmiş olması veya bu malın üzerinde kamu görevlisinin koruma ve gözetim yükümlülügünün bulunması gerekir. Kamu görevlisinin zilyetliğinde bulunan ve koruma ve gözetimiyle yükümlü bulunduğu mallar mülkiyetinin devlete, herhangi bir kamu kurumuna veya kişiye ait olması arasında fark bulunmamaktadır (Türkiye Cumhuriyeti Adalet Bakanlığı, 2003:265). 5237 sayılı Kanun'a göre ancak bir kamu görevlisi zimmet suçunun faili olabilirken (Aslan, 2013:49) mağdur ise tüm toplumdur. Diğer taraftan zimmet konusu malın sahibi olan kişi de aynı zamanda toplumun bir ferdi olarak mağdur olarak kabul edilmelidir (İtişgen, 2013:644).

\section{Araştırma}

$\mathrm{Bu}$ araştırmada, kamu sektörünün maruz kaldığı hileler arasında yer alan zimmet eylemlerinin cinsiyet, bölge ve yıl değişkenleri temelinde analiz edilmesi amaçlanmaktadır. Araştırma kapsamında Türkiye'de 2009-2017 yılları arasında gerçekleştirilen suç istatistikleri taranmış ve bunlar arasında yer alan zimmet suçlarına ilişkin veriler ayrıntılı olarak incelenmiştir.

\subsection{Araştırmanın Yöntemi}

Araştırmada doküman incelemesi şeklindeki veri toplama tekniği ile elde edilen ikincil veriler kullanılmıştır. Analizlere esas teşkil eden veriler Adalet Bakanlığı'nın resmi internet sitesindeki suç istatistiklerini içeren dokümanlardan elde edilmiştir. 5237 say1lı Kanun'un 247'inci maddesine istinaden 2009 ile 2017 yılları arasında ceza mahkemelerinde açılan zimmet davası 
sayıları baz veri olarak kabul edilmiştir (Adalet Bakanlı̆̆1, 2019a:1-209; Adalet Bakanlığ1, 2019b:1163; Adalet Bakanlığ1, 2019c:1-235; Adalet Bakanlığ1, 2019ç:1-255; Adalet Bakanlığ1, 2019d:1-528; Adalet Bakanlığı, 2019e:1-282; Adalet Bakanlığı, 2019f:1-270; Adalet Bakanlığı, 2019g:1-272; Adalet Bakanlığı, 2019h:1-270). Bakanlığın resmi internet sitesinden temin edilen veriler üzerinde normal dağılım analizi yapılmıştır. Analizler sonucunda normal dağılıma sahip olmadığı belirlenen veriler üzerinde parametrik olmayan testler uygulanmıştır. Bu kapsamda SPSS PASW 18 Statistics programı aracılığıyla yıllar içinde işlenen zimmet suçlarının sayısı baz alınarak frekans analizi ile cinsiyet temelinde Mann-Withney U testi, bölgeler ve ylllar temelinde ise Kruskall-Wallis H testleri gerçekleştirilmiştir. Cinsiyet, bölge ve yıllar bazında 126 serbestlik derecesine sahip veri analizlere dahil edilmiştir.

Kamu personeli sayıları nüfus farklılığının bir sonucu olarak bölgeler arasında değişkenlik göstermektedir. Bölgelere göre kamu personeli sayılarına ulaşılamamış olup bu sebeple analizler 2017 nüfus sayımı sonuçlarına göre bölgelerin toplam nüfusları baz alınarak gerçekleştirilmiştir. Bölgeler temelinde gerçekleştirilen fark testleri için toplam zimmet sayılarının veri olarak kabul edildiği fark analizinin yanında her bölgede 1.000 .000 nüfusa düşen zimmet sayıları hesaplanarak bu veriye dayalı olarak da fark analizi gerçekleştirilmiştir. Türkiye İstatistik Kurumu'ndan 2017 y1lına ilişkin nüfus sayıları temin edilmiştir. Buna göre 2017 yılında İç Anadolu'da 12.895.988 kişi, Karadeniz'de 7.782.736 kişi, Akdeniz'de 10.303.984 kişi, Ege'de 10.383.963 kişi, Doğu Anadolu'da 5.962.666 kişi, Güneydoğu Anadolu'da 8.665.165 kişi ve Marmara'da 24.816.023 kişi yaşamaktadır (Türkiye İstatistik Kurumu, 2019). Söz konusu bölgeleri oluşturan şehirlerde kamu personeli tarafından gerçekleştirilen zimmet eylemleri toplamı nüfus sayısına bölünerek 1.000 .000 rakamı ile çarpılmış ve 1.000 .000 kişiye düşen zimmet sayısına ulaşılmıştır. Son olarak hesaplamalara Adalet Bakanlığı istatistiklerinde cinsiyet bilgisi yer almayan kamu personeli dahil edilmemiştir.

Kamu sektöründe çalışan kişilerin sayıları cinsiyet açısından önemli fark taşımaktadır. Erkek çalışanların (\%62 ve 1,9 milyon) kadın çalışanlardan (\%37 ve 1,2 milyon) çok daha fazla sayıda kamuda istihdam edildiği görülmektedir (Devlet Personel Başkanlığı, 2019:1). Bu sebeple cinsiyet açısından fark analizleri yapılırken yine 100.000 kamu personeli başına düşen zimmet sayıları baz alınmıştır. $\mathrm{Bu}$ sebeple işlenen zimmet suçları kamuda çalışan toplam kadın ve erkek sayısına bölünerek 100.000 ile çarpılmak suretiyle 100.000 personel başına düşen zimmet suçlarına ulaşı1mıştır.

\subsection{Yıllar İtibarıyla Zimmet Suçlarının Cinsiyete ve Bölgelere Göre Frekans Analizi} verilmiştir.

$\mathrm{Bu}$ bölümde zimmet suçlarının yıllar itibarıyla bölgelere göre frekans analizine yer 
Tablo 3: Yıllar İtibarıyla Zimmet Suçlarının Cinsiyet ve Bölgelere Göre Frekans Analizi

\begin{tabular}{|c|c|c|c|c|c|c|c|c|c|c|c|}
\hline Bölge & Cinsiyet & $\begin{array}{c}2009 \\
(\text { ZS-O) }\end{array}$ & $\begin{array}{c}2010 \\
(\mathrm{ZS}-\mathrm{O})\end{array}$ & $\begin{array}{c}2011 \\
(\mathrm{ZS}-\mathrm{O})\end{array}$ & $\begin{array}{c}2012 \\
(\mathrm{ZS}-\mathrm{O})\end{array}$ & $\begin{array}{c}2013 \\
(\mathrm{ZS}-O)\end{array}$ & $\begin{array}{c}2014 \\
\text { (ZS-O) }\end{array}$ & $\begin{array}{c}2015 \\
(\mathrm{ZS}-\mathrm{O})\end{array}$ & $\begin{array}{c}\begin{array}{c}2016 \\
(Z S-O)\end{array} \\
\end{array}$ & \begin{tabular}{|c|}
2017 \\
(ZS-O)
\end{tabular} & TOPLAM \\
\hline \multirow{2}{*}{ Marmara } & Erkek & 791 & 652 & 667 & 889 & 809 & 812 & 649 & 570 & 338 & $6177 / \% 18,87$ \\
\hline & Kadın & 74 & 49 & 58 & 90 & 77 & 82 & 71 & 39 & 32 & $572 / \% 1,84$ \\
\hline \multirow[b]{2}{*}{ Ege } & Erkek & 499 & 527 & 412 & 425 & 642 & 803 & 535 & 366 & 264 & $4473 / \% 14,39$ \\
\hline & Kadın & 37 & 46 & 44 & 43 & 73 & 156 & 61 & 52 & 43 & $555 / \% 1,79$ \\
\hline \multirow{2}{*}{$\begin{array}{l}\text { İç } \\
\text { Anadolu }\end{array}$} & Erkek & 517 & 643 & 518 & 624 & 1276 & 516 & 532 & 602 & 316 & $5544 / \% 17,84$ \\
\hline & Kadın & 21 & 28 & 38 & 46 & 193 & 41 & 61 & 75 & 23 & $526 / \% 1,69$ \\
\hline \multirow{2}{*}{ Akdeniz } & Erkek & 460 & 497 & 439 & 636 & 498 & 394 & 315 & 316 & 317 & $3872 / \% 12,46$ \\
\hline & Kadın & 40 & 34 & 40 & 57 & 63 & 34 & 40 & 18 & 40 & $366 / \% 1,18$ \\
\hline \multirow{2}{*}{ Karadeniz } & Erkek & 278 & 327 & 382 & 379 & 293 & 248 & 217 & 160 & 133 & $2417 / \% 7,78$ \\
\hline & Kadın & 15 & 18 & 35 & 20 & 26 & 11 & 7 & 17 & 9 & 0,51 \\
\hline \multirow{2}{*}{$\begin{array}{l}\text { Doğu } \\
\text { Anadolu }\end{array}$} & Erkek & 233 & 209 & 228 & 198 & 157 & 208 & 127 & 112 & 103 & 5,06 \\
\hline & Kadın & 20 & 18 & 8 & 4 & 6 & 8 & 6 & 10 & 3 & $83 / \% 0,26$ \\
\hline \multirow{2}{*}{$\begin{array}{l}\text { Güneydoğ } \\
\text { u Anadolu }\end{array}$} & Erkek & 143 & 164 & 90 & 203 & 182 & 129 & 86 & 118 & 1601 & $2716 / \% 8,74$ \\
\hline & Kadın & 6 & 8 & 8 & 10 & 6 & 5 & 1 & 12 & 1988 & $2044 / \% 6,58$ \\
\hline \multirow{2}{*}{ Toplam } & Erkek & $\begin{array}{c}2921 / \\
\% 93,20\end{array}$ & $\begin{array}{c}3019 \\
1 \% 93,75\end{array}$ & $\begin{array}{c}2736 \\
1 \% \\
92,21\end{array}$ & $\begin{array}{c}3354 / \\
\% \\
92,55\end{array}$ & $\begin{array}{c}3857 \\
1 \% \\
89,67\end{array}$ & $\begin{array}{c}3110 / \\
\% \\
90,22\end{array}$ & $\begin{array}{c}2461 / \\
\% \\
90,88\end{array}$ & \begin{tabular}{|c|}
$2244 /$ \\
$\%$ \\
90,96
\end{tabular} & $\begin{array}{c}3072 / \\
\% \\
58,96\end{array}$ & $26774 / \% 86,15$ \\
\hline & Kadin & $\begin{array}{c}213 / \\
\% 6,80\end{array}$ & $\begin{array}{c}201 / \\
\% 6,26\end{array}$ & $\begin{array}{c}231 / \\
\% 7,79\end{array}$ & $\begin{array}{c}270 / \\
\% 7,45\end{array}$ & $\begin{array}{c}444 / \\
\% \\
10,33\end{array}$ & $\begin{array}{c}337 / \\
\% 9,78\end{array}$ & $\begin{array}{c}247 / \\
\% 9,12\end{array}$ & $\begin{array}{c}223 / \\
\% 9,04\end{array}$ & $\begin{array}{c}2138 / \\
\% \\
41,04\end{array}$ & $4304 / \% 13,85$ \\
\hline TOI & & $\begin{array}{c}3134 / \\
\% 10,08\end{array}$ & $\begin{array}{c}3220 / \\
\% 10,36\end{array}$ & $\begin{array}{c}2967 / \\
\% 9,54\end{array}$ & $\begin{array}{c}3624 / \\
\% \\
11,66\end{array}$ & $\begin{array}{c}4301 / \\
\% \\
13,83\end{array}$ & $\begin{array}{c}3447 / \\
\% \\
11,09\end{array}$ & $\begin{array}{c}2708 / \\
\% 8,71\end{array}$ & $\begin{array}{c}2467 / \\
\% 7,93\end{array}$ & $\begin{array}{c}5210 / \\
\% \\
16,76 \\
\end{array}$ & 31078 \\
\hline
\end{tabular}

Not: ZS-O:Zimmet Sayıs1-Oran1.

Tabloya göre 2009-2017 yılları arasında toplam 31078 adet zimmet davasının açıldığı, bunların içinde erkek çalışanlar için açılan davaların \%86,15 oran ile kadınlara nazaran $(\% 13,85)$ çok yüksek olduğu görülmektedir. Aynı dönemde Marmara Bölgesi’nde açılan zimmet davaları $\% 20,7$ ile (6749 adet) bölgeler arasında ilk sırayı oluşturmakta ve hemen ardından \%19,5 oran ile (6070 adet) İç Anadolu Bölgesi gelmektedir. Marmara Bölgesi’nde nüfus yoğunluğunun ve buna bağlı olarak kamu personeli sayısının fazla olması yüksek sayıda zimmet davası açılmasını açıklayan nedenlerden birisi olarak düşünülebilir. Ancak İç Anadolu Bölgesi nüfus bakımından Marmara Bölgesi'nin çok altında olmasına rağmen yüksek sayıda zimmet davası açılması dikkat çekmektedir. $\mathrm{Bu}$ durumun başkent olması sebebiyle Ankara'da kamu kurumlarının ve dolayısıyla da kamu personelinin yoğunluk arz etmesinden kaynaklı olabileceği söylenebilir. Son olarak \%16,76 oran ile (5210 adet) en fazla zimmet davasının 2017 yılında açıldığı görülmektedir.

\subsection{Cinsiyete Göre Zimmet Suçlarına İlişsin Fark Testi}

Bu bölümde kamu personelinin işlediği zimmet suçu sayısının cinsiyete göre anlamlı bir farklılık taşıııp taşımadığının tespit edilmesi amacıyla parametrik olmayan testlerden MannWithney U testi yapılmıştır. Kamuda çalışan personel sayıları cinsiyet açısından çok büyük fark taşıdığ 1 için analizlerin anlamlı olmasını temin etmek amacıyla 100.000 kadın ve 100.000 erkek kamu personeli başına düşen zimmet sayıları üzerinden fark testleri gerçekleştirilmiştir. Öncelikle verilere ilişkin normallik dağılımı analizi sonuçları sunularak ardından fark testi sonuçlarına yer verilmiştir. Bu kapsamda aşağıdaki hipotezler test edilmiştir:

H0: Cinsiyete göre işlenen zimmet eylemi sayısı açısından anlamlı bir fark yoktur ( $p>0,05)$,

H1: Cinsiyete göre işlenen zimmet eylemi sayısı açısından anlamlı bir fark vardır. 
Tablo 4: Normallik Testi Sonuçları

\begin{tabular}{|l|l|r|r|r|r|r|r|}
\hline & & \multicolumn{3}{|c|}{ Kolmogorov-Smirnov $^{\mathbf{a}}$} & \multicolumn{3}{|c|}{ Shapiro-Wilk } \\
\cline { 3 - 8 } & Cinsiyet & Statistic & df & Sig. & Statistic & df & Sig. \\
\hline $\begin{array}{l}\text { Cinsiyet100bin } \\
\text { perzimmet }\end{array}$ & Erkek &, 116 & 63 &, 035 &, 872 & 63 &, 000 \\
\cline { 3 - 8 } & Kadın &, 418 & 63 &, 000 &, 190 & 63 &, 000 \\
\hline
\end{tabular}

Normallik testlerinden Kolmogorov-Smirnov testi (50'den daha fazla veri) sonuçları baz alınmıştır. Buna göre değişkenlere ilişkin test sonuçları 0,05 anlamlılık düzeyinden daha düşük olduğu için verilerin normal dağılıma sahip olmadığı belirlenmiştir.

Tablo 5: Mann-Withney U Testi Sıra Ortalamaları (Bölgeler Bazında 1.000.000 Kişiye Düşen Zimmet Sira Ortalamaları)

\begin{tabular}{|l|l|l|l|l|}
\hline & Cinsiyet & N & Mean Rank & Sum of Ranks \\
\hline \multirow{4}{*}{ Cinsiyet100binperzimmet } & Erkek & 63 & 92,46 & 5825 \\
\cline { 2 - 5 } & Kadın & 63 & 34,54 & 2176 \\
\cline { 2 - 5 } & Total & 126 & & \\
\hline
\end{tabular}

Yukarıda yer alan Mann-Withney U Testi Ortalamalanı tablosunda erkeklerin 92,46 ve kadınların 34,54 sıra ortalamasına sahip olduğu görülmektedir.

Tablo 6: Mann-Withney U Testi Sonuçları (100.000 Personel Başına Düşen Zimmet Sayıs1)

\begin{tabular}{|c|c|}
\hline & Cins100binperzimzet \\
\hline Mann-Whitney U & 160 \\
\hline Wilcoxon W & 2176 \\
\hline Z & $-8,903$ \\
\hline Asymp. Sig. (2-tailed) &, 000 \\
\hline
\end{tabular}

Mann-Withney U testi neticesinde kamu sektöründe çalışan kadın ve erkekler arasında zimmet eylemini gerçekleştirme yönüyle anlamlı bir farklılık bulunduğu $(p<0,05)$, erkeklerin kadınlara kıyasla daha çok zimmet suçu girişimi gerçekleştirdiği saptanmıştır. Buna göre $\mathrm{H}_{1}$ hipotezi kabul edilmiştir.

\subsection{Bölgeye Göre Zimmet Suçlarına İlişkin Fark Testi}

Bu bölümde kamu personelinin işlediği zimmet suçu sayısının bölgeye göre anlamlı bir farklılık taşıyıp taşımadığının tespit edilmesi amacıyla parametrik olmayan testlerden KruskallWallis $\mathrm{H}$ testi yapılmıştır. Bölgeler arasında yüksek seviyede nüfus farklılıklarının bulunması sebebiyle fark testinin anlamlı olmasını sağlamak için her bölgede 1.000.000 kişi başına düşen zimmet sayıları temel alınarak fark testleri gerçekleştirilmiştir. Öncelikle verilere ilişkin normallik dağılımı analizi sonuçları sunularak ardından fark testi sonuçlarına yer verilmiştir. $\mathrm{Bu}$ kapsamda aşağıdaki hipotezler test edilmiştir:

H0: Bölgeye göre işlenen zimmet eylemi sayısı açısından anlamlı bir fark yoktur ( $p>0,05)$,

H1: Bölgeye göre işlenen zimmet eylemi sayısı açısından anlamlı bir fark vardır. 


\begin{tabular}{|l|l|c|c|c|c|c|c|}
\hline \multicolumn{9}{c}{ Tablo 7: Normallik Testi Sonuçları } \\
\hline \multirow{4}{*}{ Bölge } & \multirow{2}{*}{ Kolmogovov-Smirnov } & \multicolumn{2}{c|}{ Shapiro-Wilk } \\
\cline { 2 - 8 } & & Statistic & df & Sig. & Statistic & df & Sig. \\
\hline \multirow{5}{*}{ Bölge 1milyon kişi başına zimmet } & Marmara &, 299 & 18 &, 000 &, 797 & 18 &, 001 \\
\cline { 2 - 8 } & Ege &, 240 & 18 &, 007 &, 856 & 18 &, 011 \\
\cline { 2 - 8 } & İç Anadolu &, 223 & 18 &, 018 &, 823 & 18 &, 003 \\
\cline { 2 - 8 } & Akdeniz &, 290 & 18 &, 000 &, 828 & 18 &, 004 \\
\cline { 2 - 8 } & Karadeniz &, 275 & 18 &, 001 &, 824 & 18 &, 003 \\
\cline { 2 - 7 } & Doğu Anadolu &, 283 & 18 &, 001 &, 808 & 18 &, 002 \\
\cline { 2 - 6 } & Güneydoğu Anadolu &, 432 & 18 &, 000 &, 491 & 18 &, 000 \\
\hline
\end{tabular}

Normallik testlerinden Shapiro-Wilk testi (50'den daha az veri) sonuçları baz alınmıştır. Buna göre değişkenlere ilişkin test sonuçları 0,05 anlamlılık düzeyinden daha düşük olduğu için verilerin normal dağılıma sahip olmadığ

Tablo 8: Kruskall-Wallis H Testi Sıra Ortalamaları (Bölgeler Bazında 1.000.000 Kişiye Düşen Zimmet Sıra Ortalamaları)

\begin{tabular}{|l|l|c|c|}
\hline & Bölge & N & Mean Rank \\
\hline \multirow{4}{*}{ Bölge 1milyon kişi başına zimmet } & Marmara & 18 & 56,67 \\
\cline { 2 - 4 } & Ege & 18 & 81,22 \\
\cline { 2 - 4 } & İç Anadolu & 18 & 73,44 \\
\cline { 2 - 4 } & Akdeniz & 18 & 73,44 \\
\cline { 2 - 4 } & Karadeniz & 18 & 60,50 \\
\cline { 2 - 4 } & Doğu Anadolu & 18 & 51,78 \\
\cline { 2 - 5 } & Güneydoğu Anadolu & 18 & 47,44 \\
\cline { 2 - 4 } & Total & 126 & \\
\hline
\end{tabular}

Yukarıda yer alan Kruskall-Wallis H Testi Ortalamalan tablosunda, Marmara'nın 56,67, Ege'nin 81,22, İç Anadolu'nun 73,44, Akdeniz'in 73,44, Karadeniz'in 60,50, Doğu Anadolu'nun 51,78 ve Güneydoğu Anadolu'nun ise 47,44 sıra ortalamalarına sahip olduğu görülmektedir.

Tablo 9: Kruskall-Wallis H Testi İstatistikleri

\begin{tabular}{|l|c|}
\hline & Bölge1 miokişibaşınazimmet \\
\hline Chi-square & 12,996 \\
\hline Df & 6 \\
\hline Asymp. Sig. &, 043 \\
\hline
\end{tabular}

Kruskall-Wallis H testi neticesinde kamu sektöründe bölgeler itibarıyla 1.000 .000 kişi başına düşen zimmet eylemi sayısında anlamlı bir farklılık bulunduğu $(\mathrm{p}<0,05)$, sıra ortalamaları temelinde en yüksek zimmet eyleminin Ege Bölgesi'nde en düşük zimmet eyleminin ise Güneydoğu Anadolu Bölgesi'nde gerçekleştiği saptanmıştır. Buna göre $\mathrm{H}_{1}$ hipotezi kabul edilmiştir.

\subsection{Yıllara Göre Zimmet Suçlarına İlişkin Fark Testi}

$\mathrm{Bu}$ bölümde kamu personelinin işlediği zimmet suçu sayısının yıllara göre anlamlı bir farklılık taşıyıp taşımadığının tespit edilmesi amacıyla parametrik olmayan testlerden KruskallWallis H testi yapılmıştır. Öncelikle verilere ilişkin normallik dağılımı analizi sonuçları sunularak ardından fark testi sonuçlarına yer verilmiştir. Bu kapsamda aşağıdaki hipotezler test edilmiştir:

H0: Yıllara göre işlenen zimmet eylemi sayısı açısından anlamlı bir fark yoktur ( $p>0,05)$,

H1: Yıllara göre işlenen zimmet eylemi sayısı açısından anlamlı bir fark vardır. 
Tablo 10: Normallik Testi Sonuçları

\begin{tabular}{|l|c|c|c|c|c|c|c|}
\hline \multirow{4}{*}{} & \multirow{2}{*}{ Yıl } & \multicolumn{3}{|c|}{ Kolmogorov-Smirnov } & \multicolumn{3}{c|}{ Shapiro-Wilk } \\
\cline { 2 - 8 } & & Statistic & df & Sig. & Statistic & df & Sig. \\
\hline \multirow{4}{*}{ Yll bazll zimmet } & 2009 &, 225 & 14 &, 052 &, 829 & 14 &, 012 \\
\cline { 2 - 8 } & 2010 &, 266 & 14 &, 008 &, 805 & 14 &, 006 \\
\cline { 2 - 8 } & 2011 &, 277 & 14 &, 005 &, 823 & 14 &, 010 \\
\cline { 2 - 8 } & 2012 &, 222 & 14 &, 059 &, 836 & 14 &, 014 \\
\cline { 2 - 8 } & 2013 &, 263 & 14 &, 010 &, 791 & 14 &, 004 \\
\cline { 2 - 8 } & 2014 &, 212 & 14 &, 089 &, 806 & 14 &, 006 \\
\cline { 2 - 8 } & 2015 &, 260 & 14 &, 011 &, 794 & 14 &, 004 \\
\cline { 2 - 8 } & 2016 &, 254 & 14 &, 015 &, 784 & 14 &, 003 \\
\cline { 2 - 8 } & 2017 &, 379 & 14 &, 000 &, 614 & 14 &, 000 \\
\hline
\end{tabular}

Normallik testlerinden Shapiro-Wilk testi (50'den daha az veri) sonuçları baz alınmıştır. Buna göre değişkenlere ilişkin test sonuçları 0,05 anlamlılık düzeyinden daha düşük olduğu için verilerin normal dağılıma sahip olmadığı belirlenmiştir.

Tablo 11: Kruskall-Wallis H Testi Sıra Ortalamaları (Yıllar Bazında Zimmet Sira Ortalamaları)

\begin{tabular}{|l|c|c|c|}
\hline & Yll & N & Mean Rank \\
\hline \multirow{4}{*}{ Yll bazlı zimmet } & 2009 & 14 & 61,96 \\
\cline { 2 - 4 } & 2010 & 14 & 63,68 \\
\cline { 2 - 4 } & 2011 & 14 & 62,93 \\
\cline { 2 - 4 } & 2012 & 14 & 66,75 \\
\cline { 2 - 4 } & 2013 & 14 & 69,57 \\
\cline { 2 - 4 } & 2014 & 14 & 64,57 \\
\cline { 2 - 4 } & 2015 & 14 & 59,86 \\
\cline { 2 - 4 } & 2016 & 14 & 58,57 \\
\cline { 2 - 4 } & 2017 & 14 & 63,61 \\
\cline { 2 - 4 } & Total & 126 & \\
\hline
\end{tabular}

Yukarıda yer alan Kruskall-Wallis H Testi Ortalamaları tablosunda, 2009-2017 yılları arasında gerçekleşen zimmet eylemlerinin birbirlerine oldukça yakın sıra ortalamalarına sahip olduğu görülmektedir.

Tablo 12: Kruskall-Wallis H Testi Sonuçları (Yıllara Zimmet Sayısı)

\begin{tabular}{|c|c|}
\hline & Yllbazlızimmet \\
\hline Chi-square &, 933 \\
\hline Df & 8 \\
\hline Asymp. Sig. &, 999 \\
\hline
\end{tabular}

Kruskall-Wallis $\mathrm{H}$ testi neticesinde kamu sektöründe yıllar itibarıly işlenen zimmet suçlarının sayısı yönüyle anlamlı bir farklılık bulunmadığı saptanmıştır. Buna göre $\mathrm{H}_{\mathrm{o}}$ hipotezi kabul edilmiştir.

Kamu personeli tarafindan işlenen zimmet suçları hile literatürü çerçevesinde değerlendirdiğinde cinsiyet açısından erkeklerin kadınlara nazaran istatistiki olarak anlamlı bir şekilde daha fazla hile girişimde bulunduğu görülmektedir. Bu durumun hile üçgeni teorisi temelinde erkeklerin kadınlara kıyasla daha fazla baskıya (mali baskı vb.) maruz kalmalarından, iç kontrol eksikliklerinden/firsatlardan daha fazla yararlanma eğilimi içinde olmalarından ve/veya kariyerlerine ilişkin olarak taşıdıkları beklentilerin karşılanmamasını psikolojik olarak daha fazla meşrulaştırma yönünde bir davranış sergilemelerinden ileri geldiği söylenebilir.

Bölge bazında en fazla zimmet eyleminin Ege'de en düşük zimmet girişiminin ise Güneydoğu Anadolu'da gerçekleştirildiği görülmektedir. Güneydoğu'da yaşam şartlarının daha 
kolay olmasının ve hayat pahalılığının görece daha az olmasının kamu personeli üzerinde oluşabilecek mali baskıyı engelleyerek zimmet girişimini baskıladığı söylenebilir. Ayrıca ahlaki yargıların Anadolu'da daha güçlü olmasının da bu tablonun oluşmasına katkı sağladığı ifade edebilir. En düşük zimmet girişiminin Doğu Anadolu ve Güneydoğu Anadolu'da gerçekleşmesi bu tespiti desteklemektedir. Ege'nin diğer bölgelere nazaran yoğun bir kırsal nüfusa sahip olmasının (Yılmaz, 2015:184) zimmet eylemlerinin yüksek olmasına etken oluşturduğu söylenebilir. Bu durum kırsalda yaşamını sürdüren ve görece daha düşük eğitim seviyesine sahip olan vatandaşların kamu personeline olan güvenlerinin suiistimale açık olması yönüyle değerlendirilebilir. Ayrıca Ege'de kamu kurumlarının iç kontrol sistemlerinde ve iç denetim uygulamalarında yaşanan boşluklar hile girişimleri açısından bir firsat zemini ortaya çıkarmış olabilir.

\section{Sonuç}

Kamu kurum ve kuruluşları, dünya çapında gerçekleştirilen hile araştırmalarında en fazla hile yapılan organizasyonlar arasında ilk sıralarda yer almaktadır. Bu durum kamu sektörünün çok çeşitli hizmetleri çok sayıda çalışan eliyle bir ülkenin her tarafına ulaştırma çabasından kaynaklanabilir. Hizmet çeşidi ve ağı ile beraberinde çalışan sayısının yüksek seviyelere ulaşması hile riskinin artmasında önemli bir etken olarak değerlendirilebilir. Kamu sektöründe ortaya çıkan söz konusu yüksek hile risklerinin yönetilmesi proaktif hile denetimi yaklaşımlarının uygulanmasını gerekli kılmaktadır. Özellikle bilgi teknolojilerinde yaşanan hızlı ve radikal gelişmeler kamu sektöründe proaktif iç denetim araçlarının kullanılabilmesi için güçlü bir zemin hazırlamaktadır. $\mathrm{Bu}$ bağlamda işlemlerin eşanlı veya gerçekleştirildikten çok kısa bir sonra kontrolüne odaklanan sürekli denetim anlayışının kamu sektöründe etkin olarak hayata geçirilmesinin kritik bir önem arz ettiği düşünülmektedir.

Kamu sektöründe sunulan hizmetlerin çeşitli olması, bunların ülke çapına yayılması ve bunun sonucunda yığın işlemlerin ortaya çıkması sebebiyle söz konusu faaliyetlerin sıra usulü ile denetlenmesi imkânı bulunmamaktadır. Bu sebeple sınırlı olan iç denetim kaynaklarının doğru yönlere kanalize edilerek etkin olarak kullanılması gerekmektedir. Kamu sektöründe hile risklerini etkin olarak yönetebilmek için ilgili suiistimallerin ihtiva ettiği nitelikler veya hile tipolojileri doğrultusunda bir iç denetim planı tasarlanmalıdır. Bu itibarla sınırlı iç denetim kaynaklarının öncelikli ve riskli alanlara tahsis edilmesi suretiyle hile risklerinin proaktif ve etkin kontrol edilmesi imkânı doğabilecektir.

Bu çalışmada Türkiye kamu sektöründe gerçekleştirilen hileli işlemlerden birisi olan zimmet vakaları incelenmiştir. 2009-2017 yılları arasında zimmet eylemleri için açılan dava sayılarından hareketle Türkiye kamu sektörüne ilişkin çeşitli analizler yapılmıştır. Gerçekleştirilen analizler sonucunda erkek kamu personelinin kadınlara nazaran anlamlı bir şekilde ve daha yüksek seviyede zimmet faili olarak öne çıktığı, bölgeler arasında zimmet suçunun işlenmesi açısından anlamlı bir farkl111k bulunduğu ve Ege'nin en yüksek, Güneydoğu Anadolu'nun ise en düşük zimmet girişiminde bulunulan bölgeler olduğu, yıllar içinde ise zimmet sayısı bakımından anlamlı bir farklılık oluşmadığı tespit edilmiştir. Cinsiyet açısından ulaşılan bulgular dünya genelinde hile konusunda en kapsamlı araştırmayı gerçekleştiren Uluslararası Sertifikalı Hile Denetçileri Birliği'nin (ACFE) raporlarında sunulan tespitlerle örtüşmektedir. Araştırmada ortaya çıkan söz konusu sonuçların Türkiye kamu sektörü tarafindan göz önünde bulundurulması, iç denetim planlamalarında ve icra süreçlerinde hile riskleri ile etkin mücadele edilebilmesi açısından faydalı olabilir.

Türkiye kamu sektöründe yürütülen iç denetim çalışmaları son yıllarda bir dönüşüm yaşamaktadır. Bu kapsamda gerçekleştirilen işlemlerin mevzuata uygunluğu açısından geriye dönük kontrolüne odaklanan ve daha çok cezalandırıcı bir algıya sahip olan teftiş faaliyetlerinin yanında kurumların faaliyetlerine değer katmak ve bunları geliştirmeyi amaçlayan iç denetim faaliyetleri 5018 sayılı Kanun'la birlikte uygulamaya konulmuştur. Böylece kamu kurumlarının operasyonel 
süreçlerinden başlayarak risk yönetimi ve iç denetim süreçlerinin güçlü iç kontrollerle desteklenmesi amaçlanmıştır.

Günümüzde kamu kurumlarında hem iç denetim birimlerinin hem de teftiş kurullarının ayrı ayrı mevcut olduğu görülmektedir. Bu durumun bir görev ve yetki çatışmasına sebebiyet vermemesi için ilgili birimler tarafından yürütülecek faaliyetlerin doğru bir planlama ve koordinasyona tabi tutulması gerekmektedir. 5018 sayılı Kanun'a göre iç denetim birimleri kontrol, denetim, inceleme ve araştırma faaliyetlerini yürütebilirken soruşturma yapmaları engellenmiştir. Bu durum uluslararası iç denetim standartları açısından değerlendirildiğinde dezavantajlı bir tablo ortaya çıkarmaktadır. Uluslararası iç denetim standartlarında her ne kadar iç denetim biriminin birincil görevinin soruşturma yapmak olmadığı vurgulansa da özellikle hileli işlemler ve usulsüzlükler konusunda görece uzman olan iç denetçiler tarafından soruşturma görevinin yürütülebileceği ifade edilmektedir. Yasal çerçevede bu doğrultuda düzenlemeler yapılmasının mevzuatın uluslararası standartlarla uyumlu bir niteliğe kavuşturulması ve hile ile daha etkin mücadele edilebilmesi açısından olumlu bir katk1 sağlayacağ 1 söylenebilir. Son olarak kamu sektöründe gerçekleştirilen hileli işlemlerin kurumlar bazında gelir (vergi vb.) ve harcama (cari harcamalar, personel harcamaları, yatırım harcamaları vb.) kalemlerinin nev'i, personelin yaşı, eğitim düzeyi ve tecrübe süresi vb. kriterler çerçevesinde sistematik olarak raporlanmasının usulsüzlüklerin tespiti ve önlenmesi açısından kritik bir önem arz ettiği ifade edilebilir. Böylece kamu sektöründe hile olgusu ile bütünleşik ve daha etkin bir mücadele yapılmasının mümkün olacağı düşünülmektedir.

\section{Kaynakça}

5 sayılı Cumhurbaşkanlığı Kararnamesi (2018, 15 Temmuz). Resmi Gazete Sayıs1: 30479

5018 sayılı Kamu Mali Kontrol Kanunu (2003, 12 Ekim). Resmi Gazete Sayıs1: 25326.

5237 sayılı Türk Ceza Kanunu (2004, 26 Eylül). Resmi Gazete Sayısı: 25611.

Adalet Bakanlığı (2003), Türk Ceza Kanunu Madde Gerekçeleri, http://www.cezabb.adalet.gov.tr/mevzuat/maddegerekce.doc (Erişim Tarihi: 22.08.2019)

Adalet Bakanlığı (2019a), Yı1lar İtibarıyla İllere Göre Ceza Mahkemelerinde Y1l İçinde Açılan Davalar ve Sanik Sayıları, http://www.adlisicil.adalet.gov.tr/acilandetayli/2017ceza/acilan/2017-5237-

\%C4\%B0LLER.pdf (Erişim Tarihi: 27.07.2019)

Adalet Bakanlığı (2019b), Yıllar İtibariyle İllere Göre Ceza Mahkemelerinde Y1l İçinde Açılan Davalar ve Sanık Sayıları, http://www.adlisicil.adalet.gov.tr/acilandetayli/2016ceza/acilan/2016-5237\%C4\%B0LLER.pdf (Erişim Tarihi: 27.07.2019)

Adalet Bakanlığı (2019c), Yıllar İtibariyle İllere Göre Ceza Mahkemelerinde Yı1 İçinde Açılan Davalar ve Sanık Sayıları, http://www.adlisicil.adalet.gov.tr/acilandetayli/2015-5237.pdf (Erişim Tarihi: 27.07.2019)

Adalet Bakanlığı (2019ç), Yıllar İtibariyle İllere Göre Ceza Mahkemelerinde Yı1 İçinde Açılan Davalar ve Sanık Sayıları, http://www.adlisicil.adalet.gov.tr/acilandetayli/2014-5237.pdf (Erişim Tarihi: 27.07.2019)

Adalet Bakanlığı (2019d), Yıllar İtibariyle İllere Göre Ceza Mahkemelerinde Y1l İçinde Açılan Davalar ve Sanık Say1ları, http://www.adlisicil.adalet.gov.tr/acilandetayli/2013-5237.pdf (Erişim Tarihi: 27.07.2019) 
Adalet Bakanlığı (2019e), Y1llar İtibariyle İllere Göre Ceza Mahkemelerinde Y1l İçinde Açılan Davalar ve Sanık Sayıları, http://www.adlisicil.adalet.gov.tr/acilandetayli/2012-5237.pdf (Erişim Tarihi: 27.07.2019)

Adalet Bakanlığı (2019f), Yıllar İtibariyle İllere Göre Ceza Mahkemelerinde Yı1 İçinde Açılan Davalar ve Sanık Sayıları, http://www.adlisicil.adalet.gov.tr/acilandetayli/2011-5237.pdf (Erişim Tarihi: 27.07.2019)

Adalet Bakanlığı (2019g), Yıllar İtibariyle İllere Göre Ceza Mahkemelerinde Yı1 İçinde Açılan Davalar ve Sanık Sayıları, http://www.adlisicil.adalet.gov.tr/acilandetayli/2010-5237.pdf (Erişim Tarihi: 27.07.2019)

Adalet Bakanlığı (2019h), Yıllar İtibariyle İllere Göre Ceza Mahkemelerinde Y1l İçinde Açılan Davalar ve Sanık Sayıları, http://www.adlisicil.adalet.gov.tr/acilandetayli/2009-5237.pdf (Erişim Tarihi: 27.07.2019)

Aslan, V. (2013), Zimmet Suçu, İstanbul Üniversitesi Hukuk Fakültesi Mecmuası, 71(1), 43-66.

Association of Certified Fraud Examiners (ACFE) (2018a), Report To The Nations 2018 Global Study on Occupational Fraud and Abuse, https://s3-us-west2.amazonaws.com/acfepublic/2018-report-to-the-nations.pdf (Erişim Tarihi: 22.08.2019)

Association of Certified Fraud Examiners (ACFE) (2018b), Report To The Nations 2018 Global Study On Occupational Fraud And Abuse - Government Edition-, https://www.acfe.com/uploadedFiles/ACFE_Website/Content/rttn/2018/RTTNGovernment-Edition.pdf (Erişim Tarihi: 22.08.2019)

Bozkurt, N. (2016), İşletmelerin Kara Deliği Hile: Çalışan Hileleri, 3.Basım, Alfa Yayınları, İstanbul.

Chartered Institute of Management Accountants (CIMA) (2009a), Fraud Risk Management: A Guide to Good Practice, https://www.cimaglobal.com/Documents/ImportedDocuments/cid_techguide_fraud_risk_m anagement_feb09.pdf.pdf (Erişim Tarihi: 22.08.2019)

Chartered Institute of Management Accountants (CIMA) (2009b), Corporate Fraud, http://www.cimaglobal.com/Documents/ImportedDocuments/cid_tg_corporate_fraud_may 09.pdf.pdf (Erişim Tarihi: 22.08.2019)

Coenen, T.L. (2008), Essentials of Corporate Fraud, John Wiley \& Sons, New Jersey.

Devlet Personel Başkanlığı (DPB) (2019), Kamu Personelinin Cinsiyetlerine Göre Dăğ1lımı, http://www.dpb.gov.tr/F/Root/dosyalar/istatistikler/kamu_per_istatistikleri/temmuz2019/20 18_1_GENELTABLO_CINSIYET.pdf (Erişim Tarihi: 27.07.2019)

DiNapoli, T.P. (2008), Red Flags for Fraud, State of New York Office of the State Comptroller.

Dursun, H. (2005), Ekonomik Suçlar ve Türkiye'deki Sürdürülebilir Kalkınmaya Etkileri, Türkiye Barolar Birliği Dergisi, 58, 215-245.

Emir, M. (2008), Hile Denetimi, Mali Çözüm Dergisi, 86, 109.121.

Gloeck, J.D. ve de Jager, H. (2005), Fraud Profiles of Public Sector Institutions in South Africa, Southern African Journal of Accountability and Auditing Research, 6(1), 49-65.

Golden, T.W., Skalak, S.L. ve Clayton M.M. (2006), A Guide to Forensic Accounting Investigation, John Wiley \& Sons. 
İç Denetim Koordinasyon Kurulu (IDDK) (2006), İç Denetçilerin Çalışma Usul ve Esasları Hakkında Yönetmelik, Resmi Gazete Sayısı: 26226.

İtişgen, R. (2013), Türk Ceza Hukukunda Zimmet Suçu, İstanbul Üniversitesi Hukuk Fakültesi Mecmuasi, 71(1), 639-672.

Kayım, A. (2009), İç Denetçiler Soruşturma Yapabilir Mi? Kamu Zararından Sorumlu Olanların Tespiti Çerçevesinde Bir Değerlendirme, Denetişim, 2, 117-125.

Okoye, E.I. ve Gbegi, D.O. (2013), Forensic Accounting: A Tool for Fraud Detection and Prevention in The Public Sector (A Study Of Selected Ministries in Kogi State), International Journal of Academic Research in Business and Social Sciences, 3(3), 1-19.

Othman, R., Aris, N.A., Mardziyah, A., Zainan, N. ve Amin, N.M. (2015), Fraud Detection and Prevention Methods in The Malaysian Public Sector: Accountants' and Internal Auditors' Perceptions, Procedia Economics and Finance, 28, 59-67.

Şahin, Ü. (2008), 5018 Sayılı Kamu Mali Yönetimi ve Kontrol Kanununda İç Denetim Sistemi, Karamanoğlu Mehmetbey Üniversitesi Sosyal ve Ekonomik Araştırmalar Dergisi, 2008(2), 289-302.

Şentürk, F. ve Kasap, M. (2013), Beyaz Yaka Suçları ve Finansal Yolsuzluklar, Çankırı Karatekin Üniversitesi IIBF Dergisi, 3(2), 143-167.

The Institute of Internal Auditors (IIA) (2009), Internal Auditing and Fraud, The IIA Research Foundation, USA.

Türkiye İstatistik Kurumu (TÜİK) (2019), Adrese Dayalı Nüfus Kayıt Sistemi Sonuçları, http://www.tuik.gov.tr/PreIstatistikTablo.do?istab_id=1590 (Erişim Tarihi: 27.07.2019)

Uzun, A.K. (2009), Kamu Yönetiminde İç Kontrol Ve İç Denetim Yaklaşımı, Denetişim, 3, 59-65.

Vona, L.W. (2008), Fraud Risk Assessment: Building A Fraud Audit Program, John Wiley \& Sons.

Yaman, A. (2011), Geleneksel Teftiş İle İç Denetim Modelinin Fonksiyonel Açıdan Değerlendirilmesi. Denetişim, 6, 22-28.

Yılmaz, M. (2015), Türkiye'de Kırsal Nüfusun Değişimi ve İllere Göre Dağılımı (1980-2012), Doğu Coğrafya Dergisi, 20 (33), 161-187. 